\title{
PRELIMINARY ANTIGENIC CHARACTERISATION OF AN ADULT WORM VOMIT PREPARATION OF Fasciola hepatica BY INFECTED HUMAN SERA
}

\author{
María Alejandra DE ALMEIDA(1), María Benardetti FERREIRA(1), Sandra PLANCHART(1), Angélica TERASHIMA(2), Vicente MACO(2), Luis MARCOS(2), \\ Eduardo GOTUZZO(2), Elizabeth SÁNCHEZ(3), César NÁQUIRA(3), José Vicente SCORZA(4) \& Renzo Nino INCANI(1)
}

\begin{abstract}
SUMMARY
Fascioliasis is an emerging/re-emerging vector-borne disease with the widest known distribution. Approximately 17 million people are infected around the world, being the Andean region the most affected area. There is an important necessity to develop sensitive and specific diagnostic tools to treat patients early and to avoid complications. In this paper we evaluated the immune response of infected humans against two antigenic preparations: the total soluble extract (FhTSE) and the adult worm vomit (FhAWV) in order to identify antigenic fractions specific for Fasciola hepatica. Both preparations were processed by SDS-PAGE and Western blot with human sera with fascioliasis (F), other parasitosis and healthy individuals. In the immunoblot of FhTSE, sera $\mathrm{F}$ recognised 16 bands with MW between eight and $110 \mathrm{kDa}$, from which those of 8, 9, 10, 38, 45 and $57 \mathrm{kDa}$ were specific. In the preparation FhAWV, sera F recognised nine bands with MW from eight to $85 \mathrm{kDa}$, from which those of 8, 12,15 and $24 \mathrm{kDa}$ were specific. Some bands of cross-reaction were evident with sera from patients with other parasitoses, more frequent with the FhTSE. Bands within the MW mentioned, particularly that of eight $\mathrm{kDa}$, have been shown to be specific by others, and deserve additional characterisation for their potential use in immunodiagnosis.
\end{abstract}

KEYWORDS: Fasciola hepatica; Western blot; Worm vomit; antigens.

\section{INTRODUCTION}

Fascioliasis is a parasitic infection caused by the flukes Fasciola hepatica and $F$. gigantica, showing the widest known adaptation to diverse environments ${ }^{18}$. The estimations have shown that approximately 17 million people are infected around the world ${ }^{19}$. It seems that the number of reported human cases is underestimated in many countries, especially where animal fascioliasis is prevalent. The acute disease may mimic a wide spectrum of hepatic and biliary pathology so that the diagnosis may be delayed ${ }^{17}$. As a result of the natural history of the disease, it can become self-limited and, after a few weeks, the patient evolves into an almost asymptomatic stage, clouding the final diagnosis. In view of these difficulties to achieve an early diagnosis, it is important to look for novel diagnostic tools based on the analysis of the major antigenic fractions of the parasite, for the development of potential diagnostic techniques. F. hepatica expresses a diversity of antigens either somatic or from excretions/secretions ${ }^{24}$. Therefore, we considered convenient the identification of the antigenic fractions of the worm that induce an immune response specific of humans, in at least two antigenic preparations: a traditional soluble extract, and a novel intestinal content preparation, in which antigens similar to those found in schistosomes ${ }^{23}$, could be sought.

\section{MATERIALS AND METHODS}

F. hepatica adult worms: Adult worms were collected from bile ducts of natural infected cattle from a local abattoir. Sixteen worms were used to obtain the total soluble extract and 37 for the intestinal content preparation.

Total soluble extract of adult worm: The total soluble extract of F. hepatica (FhTSE) was obtained as described elsewhere ${ }^{28}$. Worms were washed out repeatedly (at least three times) of blood, bile and debris in $0.01 \mathrm{M}$ cold PBS $\mathrm{pH}$ 7.2. They were then homogenised in a tissue grinder with teflon pestle in cold PBS, complemented with phenylmethylsulfonyl fluoride (PMSF) $1 \mathrm{mM}$ and leupeptine at $0.5 \mu \mathrm{g} / \mathrm{mL}$, as protease inhibitors. The material was centrifuged at $12.000 \mathrm{~g}$ for 30 minutes at $4{ }^{\circ} \mathrm{C}$ and the supernatant was kept in aliquots at $-70{ }^{\circ} \mathrm{C}$ until used.

Intestinal content preparation: The antigen of the vomit of adult worms of F. hepatica (FhAWV) was obtained according to the protocol described for Schistosoma mansoni by Cesari (personal communication), and modified by the authors. Worms were washed three times in $0.9 \mathrm{M} \mathrm{NaCl}$ at room temperature until the supernatant

Financial support: CDCH- Universidad de Carabobo-2002-007, Venezuela.

(1)Departamento de Parasitología, Facultad de Ciencias de la Salud, Universidad de Carabobo, Valencia, Venezuela.

(2)Instituto de Medicina Tropical Alexander von Humboldt, Universidad Peruana Cayetano Heredia, Lima, Perú.

(3)Instituto Nacional de Salud, Lima, Perú.

(4)Centro de Investigaciones "José Witremundo Torrealba", Universidad de los Andes, Trujillo, Venezuela.

Correspondence to: R.N. Incani, Tel.: 58-241-867 5017, Fax: 58-241-843 1938. E-mail: rincani@uc.edu.ve 
was clear, after which they were placed in a Petri dish with fresh cold $\mathrm{NaCl}$ and incubated at $4{ }^{\circ} \mathrm{C}$ for $45 \mathrm{~min}$. The supernatant was discarded and the worms were then incubated at $37^{\circ} \mathrm{C}$ for $30 \mathrm{~min}$ in $\mathrm{NaCl} 0.9 \mathrm{M}$, and the supernatant with evident black intestinal content collected. This material was centrifuged at $12,000 \mathrm{~g}$ and the supernatant concentrated osmotically using dialysis tubing immersed in powdered polyethilenglycol (Aquaside ${ }^{\circledR}$ ). The concentrated material was aliquoted and stored at $-70{ }^{\circ} \mathrm{C}$ until used.

Protein concentration: The protein concentration for each antigenic preparation was determined according to BRADFORD ${ }^{2}$.

Human sera: Sera from seven $F$. hepatica infected individuals (five from Peru and two from Venezuela) were used. Six sera from healthy individuals were employed as negative controls. For the evaluation of cross-reactions, 23 sera from patients with the following parasitic infections were used: visceral leishmaniasis (4), Chagas disease (3), hymenolepiasis nana (2), strongyloidiasis (3), cysticercosis (4) and schistosomiasis mansoni (7).

SDS-PAGE of the antigenic preparations: For both antigenic preparations, FhTSE and FhAWV, $75 \mu \mathrm{L}$ containing $0.4 \mu \mathrm{gr} / \mu \mathrm{L}$ of proteins per gel were analysed by SDS-PAGE $15 \%{ }^{16}$, using the Mini Protean II System (Bio Rad). Samples were runned at a constant current of $200 \mathrm{~V}$ for $40 \mathrm{~min}$ at $20^{\circ} \mathrm{C}$, under reducing (B-mercaptoethanol) and not reducing conditions. MW patterns used were Wide Range (BIORAD) for FhTSE and Blue Range (Pierce) for FhAWV. The gels were stained with Coomasie blue for protein visualisation.

Western blot analysis: Gels of both antigenic preparations were electro transferred to nitrocellulose membranes ${ }^{30}$ of $0.45 \mu \mathrm{m}$ (Bio$\mathrm{Rad})$, at a constant current of $125 \mathrm{mAmp}$ for $2 \mathrm{~h}$ at $20^{\circ} \mathrm{C}$. Membranes were blocked in PBS-Tween $200.05 \%+5 \%$ skimmed milk overnight at $4{ }^{\circ} \mathrm{C}$. These membranes were then incubated with patient sera diluted 1:100 in PBS-Tween $200.05 \%+5 \%$ skimmed milk for $90 \mathrm{~min}$ at room temperature with gentle shaking. They were then incubated with an anti human IgG peroxidase conjugate (SIGMA) 1:500 overnight at $4{ }^{\circ} \mathrm{C}$

\section{RESULTS}

Protein composition of the preparations FhTSE and FhAWV of F. hepatica: In the SDS-PAGE gels of FhTSE under reducing (R) and not reducing (NR) conditions, 17 and 19 protein bands were observed respectively (Fig. 1). For the $\mathrm{R}$ condition bands from two to $80 \mathrm{kDa}$ were observed, from which four were from two to $10 \mathrm{kDa}$ and 13 from 25 to $80 \mathrm{kDa}$. For the NR condition bands runned from two to $110 \mathrm{kDa}$, from which a group of four bands migrated from two to $10 \mathrm{kDa}$ and a group of 15 bands migrated between 19 to $110 \mathrm{kDa}$. FhAWV showed a reduced number of bands (compared to FhTSE) of approximately 10 (R) and $11(\mathrm{NR})$, in both cases between eight and $60 \mathrm{kDa}$.

Western blots of the FhTSE preparation: The immunoblot of the FhTSE under reducing conditions (Fig. 2), showed that patients infected with $F$. hepatica recognised 16 bands with MW between eight and $110 \mathrm{kDa}$. From these, six bands (approximately 8, 9, 10, 38, 44-46 and $57 \mathrm{kDa}$ ) were recognised specifically by these patients and not by individuals infected with other parasites tested. The band of $8 \mathrm{kDa}$

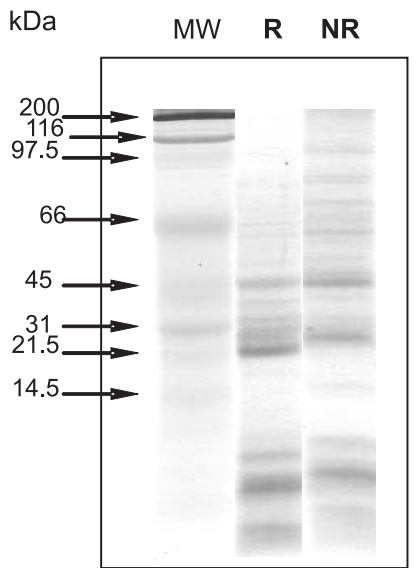

(a)

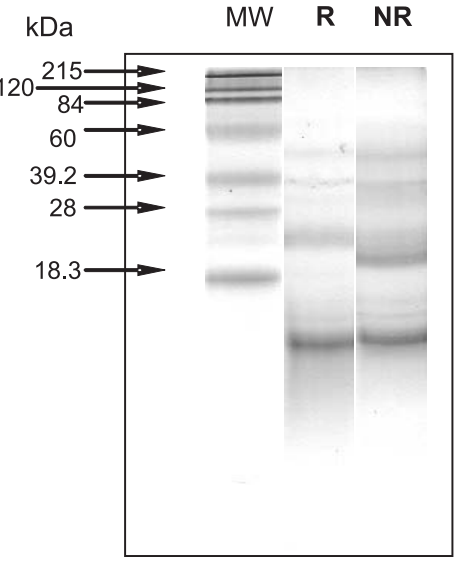

(b)
Fig. 1 - SDS-PAGE (15\%) of total soluble extract (a) and adult worm vomit (b) of Fasciola hepatica, stained with Coomasie blue.

was detected by $85.7 \%(6 / 7)$ of $F$. hepatica infected sera, those of 9 , 10 and $44-46 \mathrm{kDa}$ by $71.4 \%(5 / 7)$, and those of 38 and $57 \mathrm{kDa}$ by $28.6 \%$ (2/7) (Fig. 2). On the other hand, 30\% (7/23) of the sera of patients infected with other parasites showed cross reaction with bands of approximately 12, 31-33, 36, 49, 53, 61, 65, 75-81, 87-93 and 107 $\mathrm{kDa}$. These sera were: visceral leishmaniasis (one of four), Chagas disease (one of three), hymenolepiasis nana (two of two), strongyloidiasis (one of three), and cysticercosis (two of four). They reacted mostly with the bands of $31-33,53$ and $107 \mathrm{kDa}$, while patients with toxoplasmosis and schistosomiasis did not evidence cross reaction (Fig. 2).

Western blots of the FhAWV preparation: The immunoblot of the FhAWV under reducing conditions (Fig. 3) showed that patients infected with $F$. hepatica recognised nine bands with MW between eight and $85 \mathrm{kDa}$. From these, four bands (approximately 8, 12, 15 and $24 \mathrm{kDa}$ ) were recognised specifically by $F$. hepatica infected patients, and not by individuals infected with other parasites tested. The bands of eight and $12 \mathrm{kDa}$ were detected by all $F$. hepatica infected sera, those of 15 and $24 \mathrm{kDa}$ by $57.1 \%$ (4/7) and $71.4 \%$ (5/7) respectively. It is worth mentioning that the less specific major bands of 19-20 and 37 $\mathrm{kDa}$ showed a $57.1 \%(4 / 7)$ and $100 \%$ sensitivity respectively (Fig. 3). On the other hand, $26 \%$ (6/23) of the sera of patients infected with other parasites showed cross-reaction with the bands of approximately 19-20, 37, 50, 60-63 and $85 \mathrm{kDa}$. The most non-specific bands were those of 37,50 and $60-63 \mathrm{kDa}$ (Fig. 3). Sera from patients showing cross-reaction were: visceral leishmaniasis (two of four), Chagas disease (one of three), hymenolepiasis nana (one of two) and strongyloidiasis (two of three). Infected sera with schistosomiasis mansoni and cysticercosis did not evidence cross-reaction. All sera, infected and non-infected, recognised two bands above $215 \mathrm{kDa}$.

\section{DISCUSSION}

The preliminary observations of the present study showed that in both, the total soluble extract of the adult worms (FhTSE) and the novel preparation of adult worm vomit (FhAWV) of $F$. hepatica, there are antigens of high specificity recognised by infected human sera. 
(a)

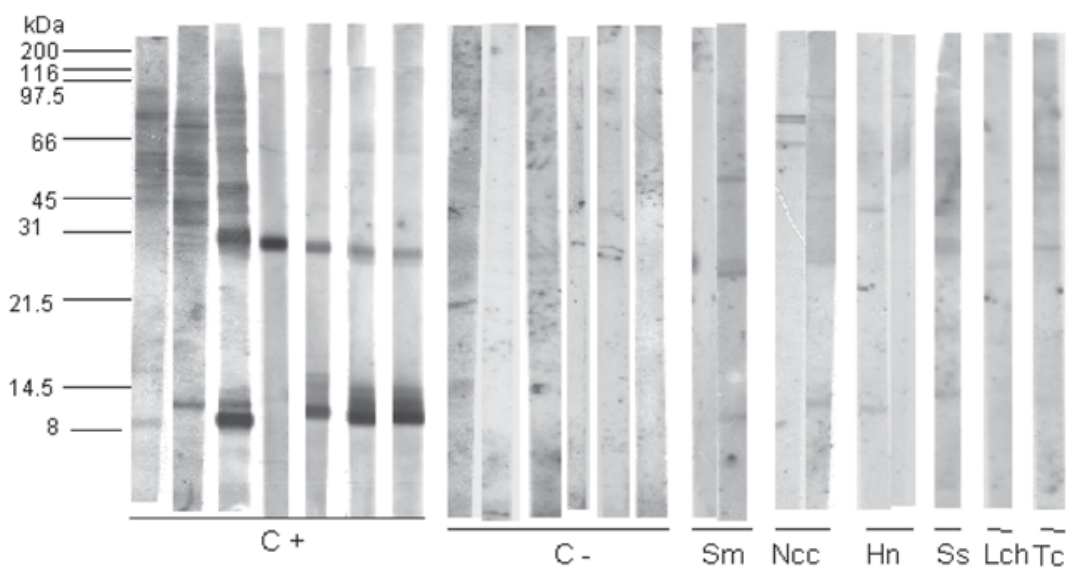

(b)

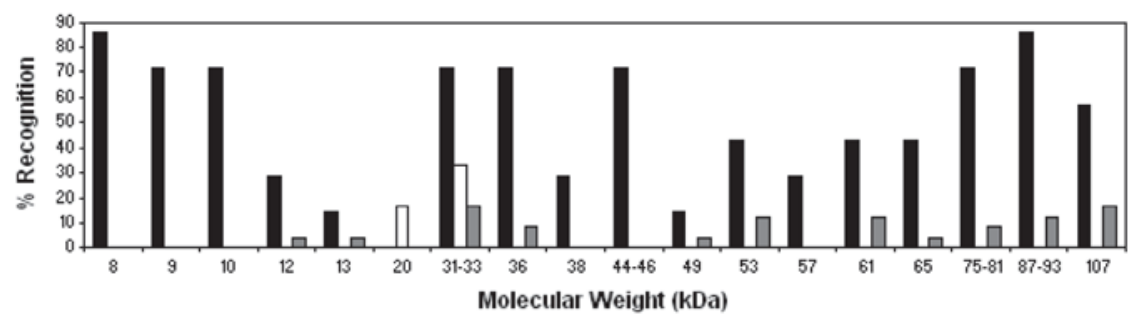

- Control + $\square$ Control - $\square$ Other parasites

Fig. 2 - Western blot of antigens (a) and percent recognition (b) in the total soluble extract of Fasciola hepatica recognised by human sera of individuals infected with F. hepatica (C+), uninfected (C-) and infected with other parasites (Sm: Schistosoma mansoni, Ncc: Neurocysticercosis, Hn: Hymenolepis nana, Ss: Strongyloides stercoralis, Lch: Leishmania chagasi and Tc: Trypanosoma cruzi).

(a)

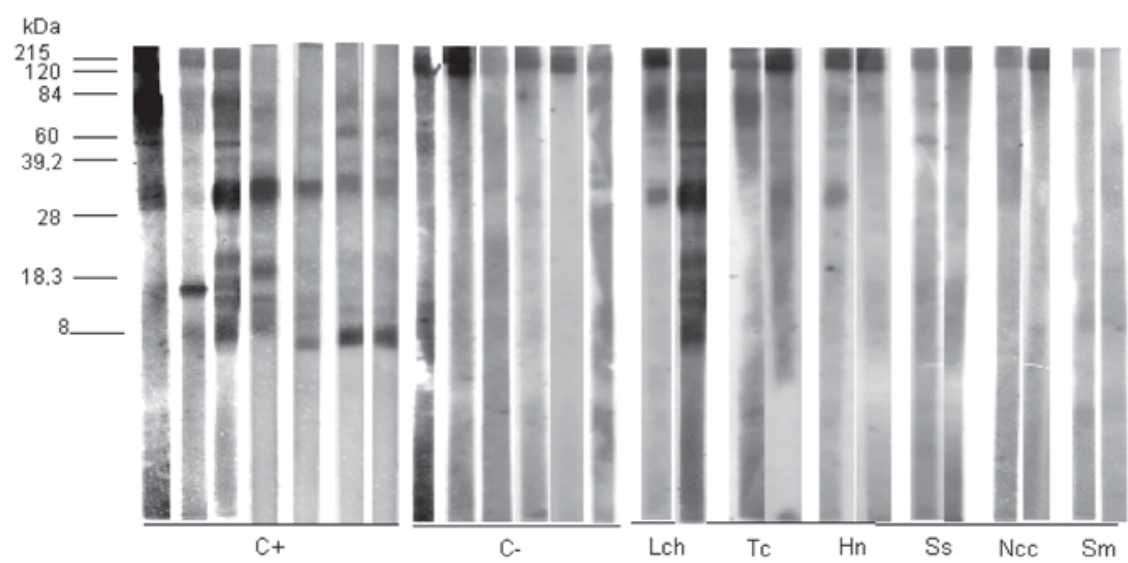

(b)

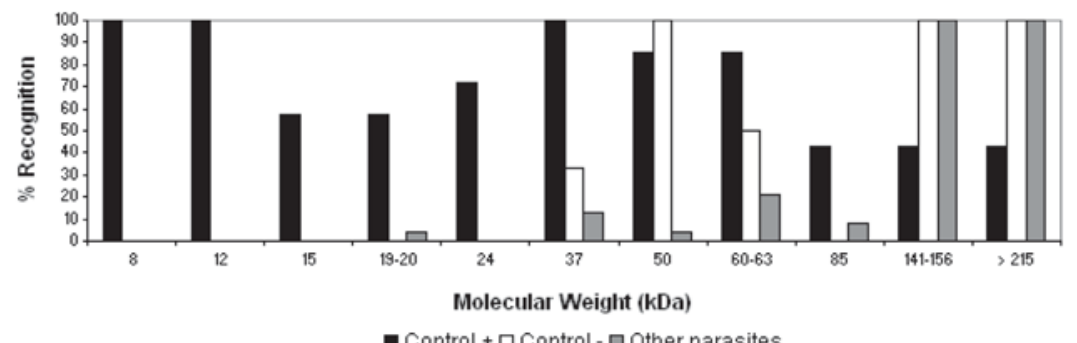

Fig. 3 - Western blot of antigens (a) and percent recognition (b) in the adult worm vomit of Fasciola hepatica recognised by human sera of individuals infected with $F$. hepatica (C+), uninfected (C-) and infected with other parasites (Sm: Schistosoma mansoni, Ncc: Neurocysticercosis, Hn: Hymenolepis nana, Ss: Strongyloides stercoralis, Lch: Leishmania chagasi and Tc: Trypanosoma cruzi). 
DE ALMEIDA, M.A.; FERREIRA, M.B.; PLANCHART, S.; TERASHIMA, A.; MACO, V.; MARCOS, L.; GOTUZZO, E.; SÁNCHEZ, E.; NÁQUIRA, C.; SCORZA, J.V. \& INCANI, R.N. Preliminary antigenic characterisation of an adult worm vomit preparation of Fasciola hepatica by infected human sera. Rev. Inst. Med. trop. S. Paulo, 49(1): 31-35, 2007.

These antigens do not appear to cross-react with sera from other parasitic infections so far tested. For the case of the FhTSE these antigens have MW of approximately 8, 9, 10, 38, 44-46 and $57 \mathrm{kDa}$. For the FhAWV, they were of $8,12,15$ and $24 \mathrm{kDa}$; those of eight and $12 \mathrm{kDa}$ were recognised by all $F$. hepatica infected sera.

Excretory-secretory (E-S) antigens have more contact with the host immune system than somatic antigens, since the parasite excretes the content of the intestine like cathepsins and other enzymes with cytolytic activities. These enzymes degrade tissues and facilitate the invasion and migration of the parasite, and induce a stronger humoral immune response, useful for diagnostic purposes and also for protection against future infections $\mathrm{s}^{5,22}$. In this sense, we developed a protocol that intended to obtain such probably less complex and more immunological specific intestinal content, rather than the classical procedure of long incubations to obtain E-S products, which may be contaminated with material from tegumental origin. We compared the antigens recognised with the protocol FhAWV, against the other classical, but less specific, total soluble extract. This methodology is new for F. hepatica, and as far as we know, it has only been employed to obtain the intestinal content of $S$. mansoni $i^{23}$.

Various authors have detected F. hepatica antigens between the MW range of 23-30 kDa during the experimental or human infection ${ }^{20,24,25}$, some as circulating antigens in serum and excreted in faeces ${ }^{1,8}$. Other antigens are gut-associated highly glycosylated proteins ${ }^{1}$ and yet others are cysteine proteinases ${ }^{3,5,6,9,26,27}$ successfully used in immunodiagnosis ${ }^{4,11,21,29}$. However, specific bands within the range of 23-30 kDa were not detected in our FhTSE, perhaps due to non use of purification procedures. However, a specific band of $24 \mathrm{kDa}$ was detected in our FhAWV but with a sensitivity of $51.7 \%$. Further characterisation of this band will be needed to define if it belongs to the cysteine proteinase group or proteoglycans of trematode gut $^{1,7}$.

On the other hand, low MW bands have also been recognised by immune sera. A cluster of polypeptides from 6.5 to $17 \mathrm{kDa}$, as circulating or copro-antigens has been observed ${ }^{8}$. A relevant molecule of $12 \mathrm{kDa}$ has been detected in sera of several animal species, which cross-reacted with $S$. mansoni $i^{13}$. This molecule was found to be a complex of at least eight isoforms of a fatty acid binding protein with different isoelectric points ${ }^{10}$. We also detected a protein of $12 \mathrm{kDa}$ in FhAWV, which was specifically recognised by all our $F$. hepatica infected sera. Since this molecule was much less represented in the FhTSE, it may be possible to think that it is of intestinal origin. Purification and characterization of this molecule should be sought since it appears to have potential for immunodiagnosis. Another immunodominant molecule of $17 \mathrm{kDa}$ recognised specifically by infected sera of humans and several animal species has been reported ${ }^{14}$. A highly sensitive and specific $14 \mathrm{kDa}$ (in addition to a $29 \mathrm{kDa}$ ) polypeptide recognised by sera from infected sheep has been also observed ${ }^{12}$. We detected a closer band $(15 \mathrm{kDa})$ specifically in our FhAWV preparation, but only with $57.1 \%$ of the F. hepatica infected human sera tested.

Finally, an antigen of eight $\mathrm{kDa}$ also deserves attention. It has been detected consistently by all our $F$. hepatica infected human sera, and not by sera from other parasitic infections so far tested. It was also detected by others ${ }^{15}$ as an immunodominant antigen in infected humans. Additionally, an eight $\mathrm{kDa}$ protein seems to be the core of a $26-28 \mathrm{kDa}$ copro-antigen. It is also a prominent band after two months of storage of copro-antigen at $4{ }^{\circ} \mathrm{C}$ and after more than 3-year storage of E-S products ${ }^{1}$. All these results suggest that the $8-\mathrm{kDa}$ antigen, as well as the $12-\mathrm{kDa}$, have relevant characteristics to be considered as a promise for the immunodiagnosis of fascioliasis in the future, and that the intestinal content or vomit preparation may be a good source of preparative material to obtain these antigens.

\section{RESUMO}

Caracterização antigênica preliminar de preparação de vômito de verme adulto de Fasciola hepatica por soros humanos infectados

Fasciolíase é uma doença emergente/re-emergente transmitida por vetores com a distribuição sabidamente mais ampla. Existem aproximadamente 17 milhões de pessoas infectadas em todo mundo, sendo a região andina a área mais afetada. Há uma necessidade importante para desenvolver ferramentas diagnósticas sensíveis e específicas para tratar cedo os pacientes e para evitar complicações. Neste trabalho avaliamos a resposta imune de seres humanos infectados comparando a duas preparações antigênicas: o extrato solúvel total (FhTSE) e o vômito (FhAWV) do verme adulto a fim de identificar as frações antigênicas específicas para Fasciola hepatica. Ambas as preparações foram processadas por SDS-PAGE e Western blot com os soros humanos de portadores de fasciolíase $(\mathrm{F})$, outras parasitoses e indivíduos saudáveis. No immunoblot de FhTSE, os soros F reconheceram 16 faixas com $\mathrm{PM}$ entre 8 e $110 \mathrm{kDa}$, das quais as de 8 , 9, 10, 38, 45 e 57 kDa foram específicas. Na preparação de FhAWV, os soros $\mathrm{F}$ reconheceram 9 faixas com PM entre 8 e $85 \mathrm{kDa}$, das quais as de $8,12,15$ e $24 \mathrm{kDa}$ foram específicas. Algumas faixas com reação cruzada foram evidentes com os soros dos pacientes com outras parasitoses, mais freqüentes com o FhTSE. As faixas dentro do PM mencionado, particularmente aquela de $8 \mathrm{kDa}$, mostraram ser específicas por outros autores, e merecem a caracterização adicional para seu uso potencial no diagnóstico imunológico.

\section{ACKNOWLEDGEMENTS}

We wish to acknowledge Italo Mario Cesari and Diana Ballén (Instituto Venezolano de Investigaciones Científicas, Caracas, Venezuela) for help in the processing of Western blot images. Our gratitude to the abattoir FRINCA, (Valencia, Venezuela) for the supply of livers from cattle infected with Fasciola hepatica.

\section{REFERENCES}

1. ABDEL-RAhMAN, S.; O'REILly, K.L. \& MALONE, J.B. - Biochemical characterization and localization of Fasciola hepatica 26-28 kDa diagnostic coproantigen. Paras. Immunol., 21: 279-286, 1999.

2. BRADFORD, M. - A rapid and sensitive method for the quantitation of micrograms quantities of protein utilizing the principle of protein-dye binding. Analyt. Biochem., 72: 248-254, 1976.

3. CARMONA, C.; DOWD, A.J.; SMITH, A.M. \& DALTON, J.P. - Cathepsin L proteinase secreted by Fasciola hepatica in vitro prevents antibody-mediated eosinophil attachment to newly excysted juveniles. Molec. Biochem. Parasit., 62: 9-17, 1993.

4. CORDOVA, M.; HERRERA, P.; NOPO, L. et al. - Fasciola hepatica cysteine proteinases: immunodominant antigens in human fascioliasis. Amer. J. trop. Med. Hyg., 57: 660-666, 1997. 
5. DALTON, J. \& HEFFERNAN, M. - Thiol proteases released in vitro by Fasciola hepatica. Molec. Biochem. Parasit., 35: 161-166, 1989.

6. DALTON, J.; O`NEILL, S.; STACK, C. et al. - Fasciola hepatica cathepsin L-like proteases: biology, function, and potential in the development of first generation liver fluke vaccines. Int. J. Parasit., 33: 1173-1181, 2003.

7. DEELDER, A.M.; KORNELIS, D.; VAN MARCK, E.A.E.; EVELEIGH, P.C. \& VAN EGMOND, J.G. - Schistosoma mansoni: characterization of two circulating polysaccharide antigens and the immunological response to these antigens in mouse, hamster and human infections. Exp. Parasit., 50: 16-32, 1980.

8. DIAZ, A.; ESPINO, A.M.; MARCET, C. et al. - Partial characterization of the epitope on excretory-secretory products of Fasciola hepatica recognized by monoclonal antibody ES78. J. Parasit., 84: 55-61, 1998.

9. DOWD, A.J.; SMITH, A.M.; McGOniGle, S. \& DALTON, J. - Purification and characterisation of a second cathepsin L proteinase secreted by the parasitic trematode Fasciola hepatica. Europ. J. Biochem., 223: 91-98, 1994.

10. ESPINO, A.M.; RODRÍGUEZ MEDINA, J.R. \& HILLYER, G.V. - Isolation and immunological characterization of fatty acid binding protein isoforms from Fasciola hepatica. J. Parasit., 87: 1028-1033, 2001.

11. ESPINOZA, J.R.; TIMOTEO, O. \& HERRERA-VELIT, P. - Fas2-ELISA in the detection of human infection by Fasciola hepatica. J. Helminth., 79: 235-240, 2005.

12. FREDES, F.; SÁNCHEZ, C.; GORMAN, T. \& ALCAÍNO, H. - Purificación de antígenos de Fasciola hepatica mediante electroelución y su aplicación inmunodiagnóstica mediante Western blot en la infección animal. Parasit. al Día, 25: 19-23, 2001.

13. HILLYER, G.V.; GARCIA-ROSA, M.I.; ALICEA, H. \& HERNÁNDEZ, A. - Successful vaccination against murine Schistosoma mansoni infection with a purified $12 \mathrm{kDa}$ Fasciola hepatica cross-reactive antigen. Amer. J. trop. Med. Hyg., 38: 103-110, 1988.

14. HILLYER, G.V. \& SOLER DE GALANES, M. - Identification of a 17-kilodalton Fasciola hepatica immunodiagnostic antigen by the enzyme-linked immunoelectrotransfer blot technique. J. clin. Microbiol., 26: 2048-2053, 1988.

15. KIM, K.; YANG, H. \& CHUNG, Y. - Usefulness of 8 kDa protein of Fasciola hepatica in diagnosis of fascioliasis. Korean J. Parasit., 41: 121-123, 2003.

16. LAEMMLI, U. - Cleavage of structural proteins during the assembly of the head of bacteriophage T4. Nature, 227: 680-685, 1970.

17. MARCOS, L.; MACO, V.; SAMALVIDES, F. et al. - Risk factors for Fasciola hepatica infection in children: a case-control study. Trans. roy. Soc. trop. Med. Hyg., 100: 158-166, 2005.

18. MAS-COMA, S. - Epidemiology of fascioliasis in human endemic areas. J. Helminth., 79: 207-216, 2005.
19. MAS-COMA, S.; BARGUES, M.D. \& ESTEBAN, J.G. - Human fasciolosis. In: DALTON, J.P., ed. Fasciolosis. New York, CABI Publishing, 1999. p. 411-434.

20. MOHAMED, M.M.; AL-SHERBINY, M.M.; SHARAF, A.A. \& ELMAMLOUK, T.H. Immunological identification of Fasciola hepatica antigens containing major human T-cell and B-cell epitopes. J. Egyp. Soc. Parasit., 34: 751-766, 2004.

21. O'NEILL, S.M.; PARKINSON, M.; DOWD, A.J. et al. - Short report: immunodiagnosis of human fascioliasis using recombinant Fasciola hepatica cathepsin L1 cysteine proteinase. Amer. J. trop. Med. Hyg., 60: 749-751, 1999.

22. PARKHOUSE, R.M.; ALMOND, N.M.; CABRERA, Z. \& HARNETT, W. - Nematode antigens in protection, diagnosis and pathology. Vet. Immunol. Immunopath., 17: 313-324, 1987.

23. PLANCHART, S.; INCANI, R.N.; BALLEN, D.; MATOS, C. \& CESARI, I. - Preliminary biochemical characterization of a Schistosoma mansoni adult worm vomit (AWV) preparation and immunological specificity of a mouse anti-AWV monoclonal antibody. In: INTERNATIONAL SYMPOSIUM ON SCHISTOSOMIASIS, 9., Salvador, 2003.

24. RUIZ-NAVARRETE, M.A.; ARRIAGA, C.; BAUTISTA, C.R. \& MORILLA, A. - Fasciola hepatica: characterization of somatic and excretory-secretory antigens of adult flukes recognized by infected sheep. Rev. latinoamer. Microbiol., 35: 301-307, 1993.

25. SANTIAGO, N.; HILLYER, G.V.; GARCIA-ROSA, M. \& MORALES, M.H. Identification of functional Fasciola hepatica antigens in experimental infections in rabbits. Amer. J. trop. Med. Hyg., 35: 135-140, 1986.

26. SMITH, A.M.; DOWD, A.J.; HEFFERNAN, M.; ROBERTSON, C.D. \& DALTON, J.P. - Fasciola hepatica: a secreted cathepsin L-like proteinase cleaves host immunoglobulin. Int. J. Parasit., 23: 977-983, 1993.

27. SMITH, A.M.; DOWD, A.J.; McGONIGLE, S. et al. - Purification of a cathepsin L-like proteinase secreted by adult Fasciola hepatica. Molec. Biochem. Parasit., 62: 1-8, 1993.

28. STRAUSS, W.; ANGLES, R.; ESTEBAN, J.G. \& MAS-COMA, S. - Human fascioliasis in Bolivia: serological surveys in Los Andes province of the Department of La Paz. Res. Rev. Parasit., 57: 109-113, 1997.

29. TIMOTEO, O.; MACO Jr., V.; MACO, V. et al. - Characterization of the humoral immune response in alpacas (Lama pacos) experimentally infected with Fasciola hepatica against cysteine proteinases Fas 1 and Fas 2 and histopathological findings. Vet. Immunol. Immunopath., 106: 77-86, 2005.

30. TOWBIN, H.; STAEHELIN, T. \& GORDON, J. - Electrophoretic transfer of proteins from polyacrylamide gels to nitrocellulose sheets: procedures and some applications. Proc. nat. Acad. Sci. (Wash.), 76: 4350-4354, 1979.

Received: 29 March 2006

Accepted: 24 July 2006 